\title{
Effect of Reducing Agents on Physical and Chemical Properties of Silver Nanoparticles
}

\author{
Roto Roto , Hani Prima Rasydta, Adhitasari Suratman, and Nurul Hidayat Aprilita \\ Department of Chemistry, Faculty of Mathematics and Natural Sciences, Universitas Gadjah Mada, \\ Sekip Utara, Yogyakarta 55281, Indonesia
}

Received July 25, 2017; Accepted July 16, 2018

\begin{abstract}
Silver nanoparticles having uniform size and shape, a diameter range of 10-50 $\mathrm{nm}$, excellent stability, and high zeta potential are always desirable for many applications. The silver nanoparticles were synthesized by chemical reduction method using some reducing agents in a polyvinyl alcohol solution. This study aims at determining the effect of reducing agents on the chemical and physical properties of silver nanoparticles. Ascorbic acid, sodium borohydride, hydrazine, sodium citrate, and glucose were used as reducing agents. Surface Plasmon Resonance (SPR) absorbance, morphology, zeta potential, crystal system, and stability of the products were studied. The results showed that the chemical and physical properties of the colloidal Ag nanoparticles were dependent on the reducing agents. In general, the produced silver nanoparticles have an fcc crystal system with a unit cell of 4.0906-4.0992 $\AA$. The SPR absorbance of the colloids has the peak in the range of 401-433 $\mathrm{nm}$. We found that the colloid of silver nanoparticles prepared by using ascorbic acid has uniform spherical shape, the diameter of about $20 \mathrm{~nm}$, and zeta potential of -10.4 $m V$. After being stored for one month, the SPR absorbance of the colloid decreased by only 5\%. This type of colloidal Ag nanoparticles prepared by using ascorbic acid is expected to be used for chemical sensors, an antibacterial agent, and so on.
\end{abstract}

Keywords: silver nanoparticles; reducing agent; SPR; zeta potential

\section{ABSTRAK}

Nanopartikel perak yang memiliki ukuran dan bentuk seragam, kisaran diameter 10-50 $\mathrm{nm}$, stabilitas sangat baik, dan potensi zeta yang tinggi selalu diinginkan untuk banyak aplikasi. Nanopartikel perak disintesis dengan metode reduksi kimia menggunakan beberapa reduktor dalam larutan polivinil alkohol. Penelitian ini bertujuan untuk menentukan pengaruh reduktor pada sifat kimia dan fisik nanopartikel perak. Asam askorbat, natrium borohidrida, hidrazin, natrium sitrat, dan glukosa digunakan sebagai reduktor. Absorbansi plasmon resonansi permukaan (SPR), morfologi, zeta potensial, sistem kristal, dan stabilitas produk dipelajari. Hasilnya menunjukkan bahwa sifat kimia dan fisik dari koloid nanopartikel Ag tergantung pada senyawa pereduksi. Secara umum, nanopartikel perak yang dihasilkan memiliki sistem kristal fcc dengan sel satuan 4,0906-4,0992 A. Absorbansi SPR koloid memiliki puncak pada kisaran 401-433 $\mathrm{nm}$. Kami menemukan bahwa koloid nanopartikel perak yang dibuat dengan menggunakan asam askorbat memiliki bentuk bulat seragam, diameter sekitar $20 \mathrm{~nm}$, dan potensial zeta -10,4 mV. Setelah disimpan selama satu bulan, absorbansi SPR koloid menurun hanya 5\%. Jenis nanopartikel Ag koloid ini diharapkan dapat digunakan untuk sensor kimia, agen antibakteri, dan sebagainya.

Kata Kunci: nanopartikel perak; agen pereduksi; SPR; zeta potensial

\section{INTRODUCTION}

In the recent years, the study on the synthesis of $\mathrm{Ag}$ nanoparticles has progressed rapidly, since the materials have many potential applications. The uses of $\mathrm{Ag}$ nanoparticles include as antibacterial agents [1-2], colorimetric sensing [3], solar cells [4], catalysts [5], etc. To meet the applications, the colloids of Ag nanoparticles must have suitable physical and chemical properties such as homogeneous shape, small and narrow particle size, and is stable for a long period. The Ag nanoparticles that have homogeneous globular shape and diameter of about

* Corresponding author.

Email address : roto05@ugm.ac.id
10-50 nm are usually needed. Also, during the application, they must be stable for a few months without forming a larger aggregate and being separated.

The preparation of the $\mathrm{Ag}$ nanoparticles itself is subject to intense investigation to obtain $\mathrm{Ag}$ nanoparticles with required physical and chemical properties. One of the many preparations of $\mathrm{Ag}$ nanoparticles is by chemical reduction using the reducing agents that include resorcinol [6], chitosan [2], and glucose [7]. They recently can also be prepared by the sonochemical method in the graphene structure [8]. 
Green synthesis by use of onion extract was applied to produce Ag nanoparticles [9].

The size, shape, and stability of the colloidal $\mathrm{Ag}$ nanoparticles are main considerations for their specific usages. The size, shape, and stability of the $\mathrm{Ag}$ nanoparticles may be controlled by use of both reducing agent and stabilizing agent. Nanoparticles produced using the reducing agent of oleylamine is stable for up to 100 days. Oleylamine is a weak reducing agent [10], which can produce a stable colloid. Biosynthesis using Trichoderma viride produces spherical, rectangular, pentagonal and hexagonal shapes of Ag nanoparticles of different dimensions with control of physical parameters, $\mathrm{pH}$, temperature, and reaction time [11].

The capping and reducing agent are responsible for crystal growth that will determine the properties of the $\mathrm{Ag}$ nanoparticles [12]. So far, to the best of our knowledge, there has been no report on the effect reducing agent on the size, shape, zeta potential, and stability of the $\mathrm{Ag}$ nanoparticles. In this paper, we report on the effect of the reducing agent on the particle size, crystal structure, stability, and zeta potential value. The objective of the work is to better understand the relationship between the reducing agent and the important characteristics of the resulting colloids.

\section{EXPERIMENTAL SECTION}

\section{Materials}

Silver nitrate, ascorbic acid, sodium citrate, glucose, polyvinyl alcohol, and hydrazine were purchased from Merck. Sigma-Aldrich supplied sodium borohydride. The chemicals were used as received. The solutions were prepared by use of double distilled water.

\section{Instrumentation}

The UV-Vis spectra or more precisely SPR spectra of the colloids were examined using a UV-Vis Shimadzu 1700-E. A Zetasizer Nano Series Malvern particle size analyzer was used to record the particle size of the products. The image of the nanoparticles was studied using TEM JEOL JEM-1400 Transmission Electron Microscope. An XRD Rigaku Mini Flex 600 diffractometer was used to examine the crystal structure of the $\mathrm{Ag}$ nanoparticles.

\section{Procedure}

An aqueous solution of silver nitrate in $0.25 \%$ PVA was prepared first using distilled water. The PVA solution was heated to boil before the dissolution of silver nitrate. The concentration of the silver nitrate stock solution was $3.0 \times 10^{-4} \mathrm{M}$. A $25 \mathrm{~mL}$ silver nitrate solution was stirred and heated to $80{ }^{\circ} \mathrm{C}$ before the addition of the reducing agent. The concentration of the reducing agent of ascorbic acid, sodium borohydride, and hydrazine was prescribed at 1.5 to $7.5 \times 10^{-4} \mathrm{M}$. The solution of reducing agent $(5 \mathrm{~mL}$ ) was added to a $25 \mathrm{~mL}$ silver nitrate solution dropwise for a total of $30 \mathrm{~min}$. For sodium citrate, the concentration was adjusted at 1.5 to $15 \times 10^{-2} \mathrm{M}$ and for glucose was set at $0.2-0.8 \mathrm{M}$. After the addition of the reducing agent, the solution was continuously stirred for an additional hour.

The colloids were analyzed by using a UV-Vis spectrometer to determine the peak absorbance and stability with a wavelength of $200-700 \mathrm{~nm}$. Colloids were also subjected to the TEM measurement for morphology analysis and particle size analysis. The nanoparticle was separated by centrifuge at a spin rate of $17000 \mathrm{rpm}$ for $20 \mathrm{~min}$. The powder was dried in the air at $50^{\circ} \mathrm{C}$ for overnight to obtain the powder before XRD data collection.

\section{RESULT AND DISCUSSION}

Fig. 1 shows the TEM images of the colloidal $\mathrm{Ag}$ nanoparticles produced in the PVA solution with different reducing agents. The particles size of $\mathrm{Ag}$ nanoparticles obtained by use of ascorbic acid give more uniform size with an average particle diameter of about $30 \mathrm{~nm}$ and spherical shape, Fig. 1(a). When glucose is used as a reducing agent, the $\mathrm{Ag}$ nanoparticles average diameter is around $20 \mathrm{~nm}$, which is smaller than that of $\mathrm{Ag}$ nanoparticles obtained by use of ascorbic acid, Fig. 1(b). The shape of the particles is spherical, but the diameter of the particles is varied. However, the size of the particles is smaller than that of $\mathrm{Ag}$ nanoparticles synthesized by using ascorbic acid.

Alginate stabilized colloidal Ag nanoparticles produced by use of reducing agent of glucose has a particle size of 3-12 nm [13]. When glucose and polysaccharide are used in place of reducing and capping agents, the particle size is about $15 \mathrm{~nm}$ [7]. The data suggest that both reducing and capping agents play an essential role in the size of prepared $\mathrm{Ag}$ nanoparticles. Strong reducing agents give big particle size. Meanwhile, weak reducing agents produce small particle size.

The Ag nanoparticles generated in the same solution by use of sodium borohydride have an average particle size comparable to the $\mathrm{Ag}$ nanoparticles acquired by use of glucose as a reducing agent. However, the diameter of the particles is similar, Fig. 1 (c). When sodium citrate was used as a reducing agent, the shape and the size changed significantly. They have many forms, i.e. hexagonal, rod, and spherical, as the majority. The bar shape has the length larger than $500 \mathrm{~nm}$. 

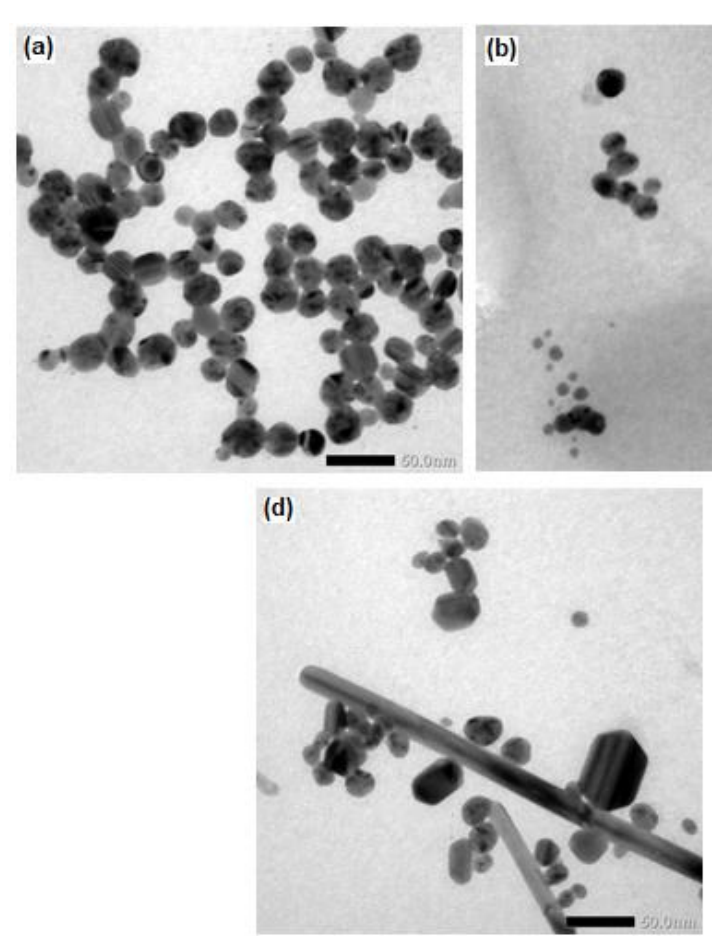
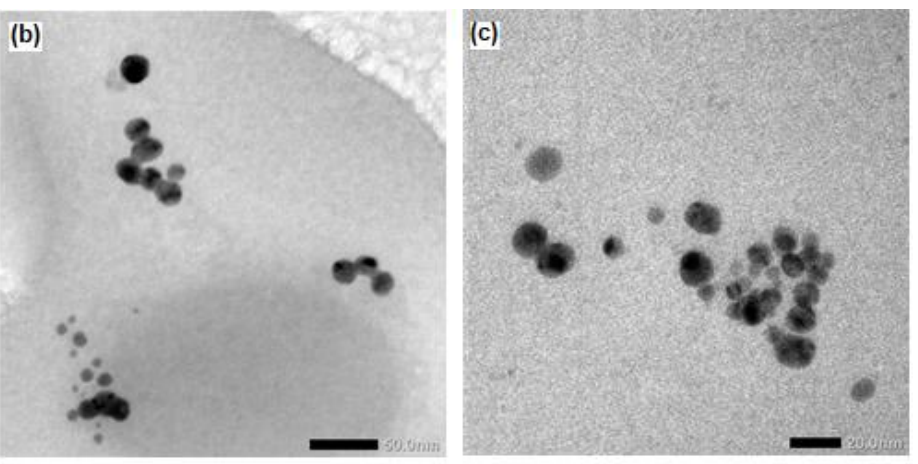

(e)

Fig 1. TEM images of Ag nanoparticle prepared by using various reducing agents; (a) ascorbic acid, (b) glucose, (c) sodium borohydride, (d) sodium citrate, (e) hydrazine



Fig 2. Particle size distribution of the Ag nanoparticles as obtained by particle size analyzer with different reducing agents, (a) ascorbic acid, (b) glucose, (c) sodium borohydride, (d) sodium citrate, and (e) hydrazine

The Ag nanoparticles prepared using the reducing agent of hydrazine have a big particle size. The shape of the particles is mainly hexagonal and round, Fig. 1(e). The size is larger than that of the fore-mentioned $\mathrm{Ag}$ nanoparticles with a diameter of more than $50 \mathrm{~nm}$.

In this work, we confirmed the particle size of the $\mathrm{Ag}$ nanoparticles by use of a particle size analyzer. Fig. 2 shows the particle size distribution of the products obtained with several reducing agents. As previously indicated in the TEM images, the Ag nanoparticles made in the PVA solution by use of ascorbic acid have much homogeneous particle size distribution, Fig. 2(a). It has a single dull peak. However, the Ag nanoparticles synthesized in the similar solution with reducing agent of glucose have a large particle size and different diameter, Fig. 2(b), as indicated by the appearance of the second peak. Sodium borohydride reducing agent gives $\mathrm{Ag}$ nanoparticles that are much bigger than that of $\mathrm{Ag}$ nanoparticles made using ascorbic acid and glucose. The particle size is much varied. There are small particles appeared when sodium citrate, Fig. 2(d). The reducing agent of hydrazine yields particles bigger than that of the particles synthesized using glucose. However, the diameter is varied, Fig. 2(e). No small particle size are detected for reducing agent of hydrazine.

Fig. 3 represents the UV-Vis spectra of colloidal Ag nanoparticles produced by using some of the reducing agents that are ascorbic acid, sodium borohydride, and hydrazine, at different series of concentration. The peak absorbance of the colloid made by using ascorbic acid bigger and narrower than that of colloid fabricated by using 

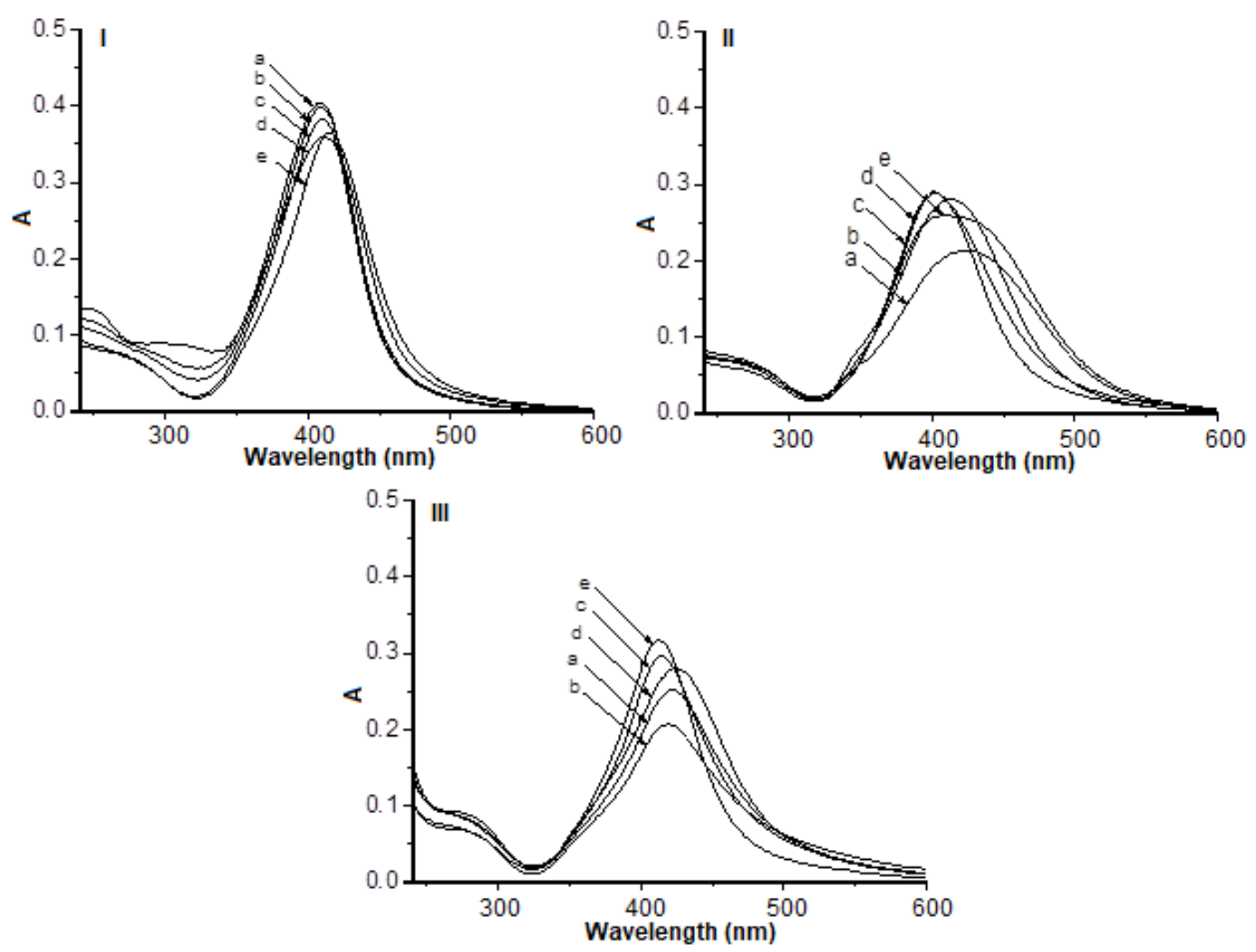

Fig 3. UV-Vis spectra of colloidal Ag nanoparticles produced by some using reducing agents, (I) ascorbic acid, (II) sodium borohydride, (III) hydrazine, at a different concentration, (a) $1.5 \times 10^{-4}$, (a) $3.0 \times 10^{-4}$, (a) $4.5 \times 10^{-4}$, (a) $6.0 \times 10^{-4}$, (a) $7.5 \times 10^{-4} \mathrm{M}$

sodium borohydride and hydrazine, Fig. 3(III). The absorbance of the colloid increases along with the increase in the concentration of $\mathrm{Ag}$ nanoparticles. The concentration of the reducing agent was observed to affect the spectra. The peaks shift to the larger wavelength when the concentration is raised.

The peak absorbance of the colloid created by using sodium borohydride is smaller than that of the colloid produced by using ascorbic acid. However, the peak of the absorbance shifts to the high wavelength for low concentration of reducing agent. The UV-Vis spectra are also wider for colloid reduced by using sodium borohydride, Fig. 3(II). Similar spectra were also observed when hydrazine was used, 3(III). For reducing agent of hydrazine, the spectra are sharper for high concentration than for low concentration. Glucose and sodium citrate give UV-Vis spectra comparable to that of sodium borohydride and hydrazine (data not shown). Also, the peak absorbance for ascorbic acid is the largest of all. The UV-Vis spectra suggest that small homogeneous particles will give the absorbance at a low wavelength and sharp peak.

The value of the zeta potential can indicate the stability of the colloid. Table 1 shows the zeta potential of the colloidal Ag nanoparticles made with different reducing
Table 1. Zeta potential of colloidal Ag nanoparticles prepared by various reducing agents

\begin{tabular}{lc}
\hline Reducing agent & Zeta potential $(\mathrm{mV})$ \\
\hline Ascorbic acid & -10.40 \\
Glucose & -4.25 \\
Sodium borohydride & -11.10 \\
Sodium citrate & -4.34 \\
Hydrazine & -4.54 \\
\hline
\end{tabular}

agents in the PVA aqueous solution. The colloid of Ag nanoparticles prepared using sodium borohydride has the zeta potential of $-11.20 \mathrm{mV}$, which is the largest. Glucose, sodium citrate, and hydrazine yield colloids with comparable zeta potentials of about $-4 \mathrm{mV}$. Meanwhile, the colloidal Ag nanoparticles prepared by using ascorbic acid give zeta potential close to that of sodium borohydride, which is $-10.40 \mathrm{mV}$. The negative value of zeta potential suggests that the colloidal $\mathrm{Ag}$ nanoparticles have a net positive charge and the surrounding stabilizing agent has a net negative charge.

When bovine serum albumin (BSA) was used as a capping agent to prepare Ag/BSA nanoparticles, it gave Zeta potential about -5 to $-9 \mathrm{mV}$ [14]. The values of zeta potential for colloids produced by the use of ascorbic acid and sodium borohydride are larger than the colloid 
Ag/BSA nanoparticles. The larger the zeta potential, the more stable the colloid would be.

The colloids of $\mathrm{Ag}$ nanoparticles are dependent on the stabilizing agents and reducing agents. The colloid can be prepared well in the dilute solution of PVA with the use of ascorbic acid and sodium borohydride. However, by considering the zeta potential, the colloid is expected to be more stable if ones use the reducing agent of sodium borohydride as reducing agent than that of the same colloids prepared by use of ascorbic acid as a reagent. The largest absolute zeta potential of the colloid is produced by using sodium borohydride. This type of colloid is very useful for long-term applications.

The XRD data determine crystalline structures of the Ag nanoparticles. Fig. 4 displays the XRD patterns of the Ag nanoparticles produced in the dilute PVA solution as a capping agent and several reducing agents. In general, the diffraction peaks correspond well to the face-centered cubic structure, fcc. The diffraction peaks appear at 2theta of $38.093,44.24,64.35,77.30,81.43$ degrees. They correspond to the Miller indices of (111), (200), (220), (311), and (222), respectively. The unit cells obtained by Bragg law are in the range 4.0906-4.0992 angstrom. Similar XRD data for Ag nanoparticles were reported previously [2]. Table 2 shows the collated unit cells of the $\mathrm{Ag}$ nanoparticles produced using various reducing agents. The data are confirmed by comparison with JCPDS Card No. 96-900-8460 [15].

Fig. 5 displays the UV-Vis spectra of the colloids of Ag nanoparticles formed by reduction with ascorbic acid,
Table 2. The unit cell value of the colloidal Ag nanoparticles synthesized by using a different reagent

\begin{tabular}{lc}
\hline Reducing agent & Unit cell $(\AA)$ \\
\hline Ascorbic acid & 4.0992 \\
Glucose & 4.0963 \\
Sodium citrate & 4.0986 \\
Sodium borohydride & 4.0991 \\
Hydrazine & 4.0906 \\
\hline
\end{tabular}

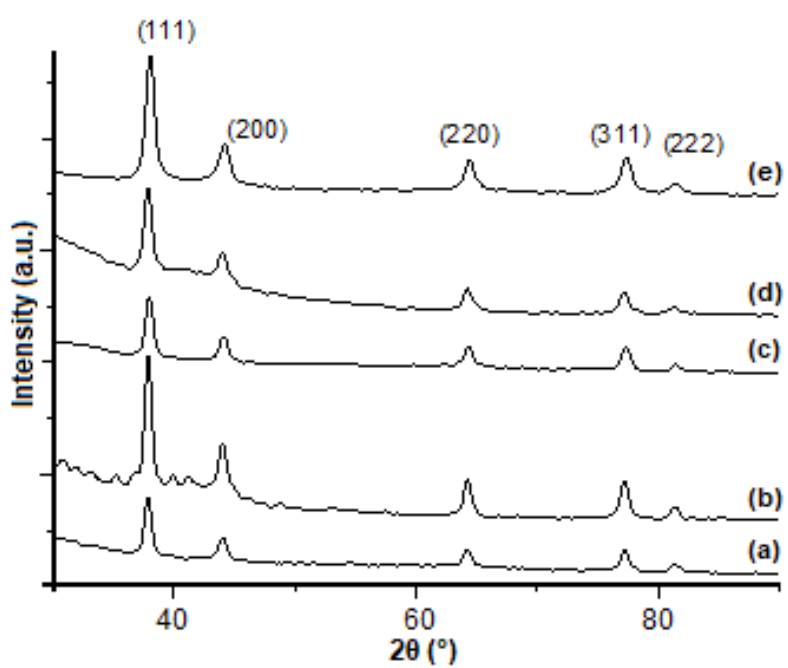

Fig 4. XRD patterns of the $\mathrm{Ag}$ nanoparticles produced using different reducing agents, (a) ascorbic acid, (b) glucose, (c) sodium nitrate, (d) sodium borohydride, (e) hydrazine
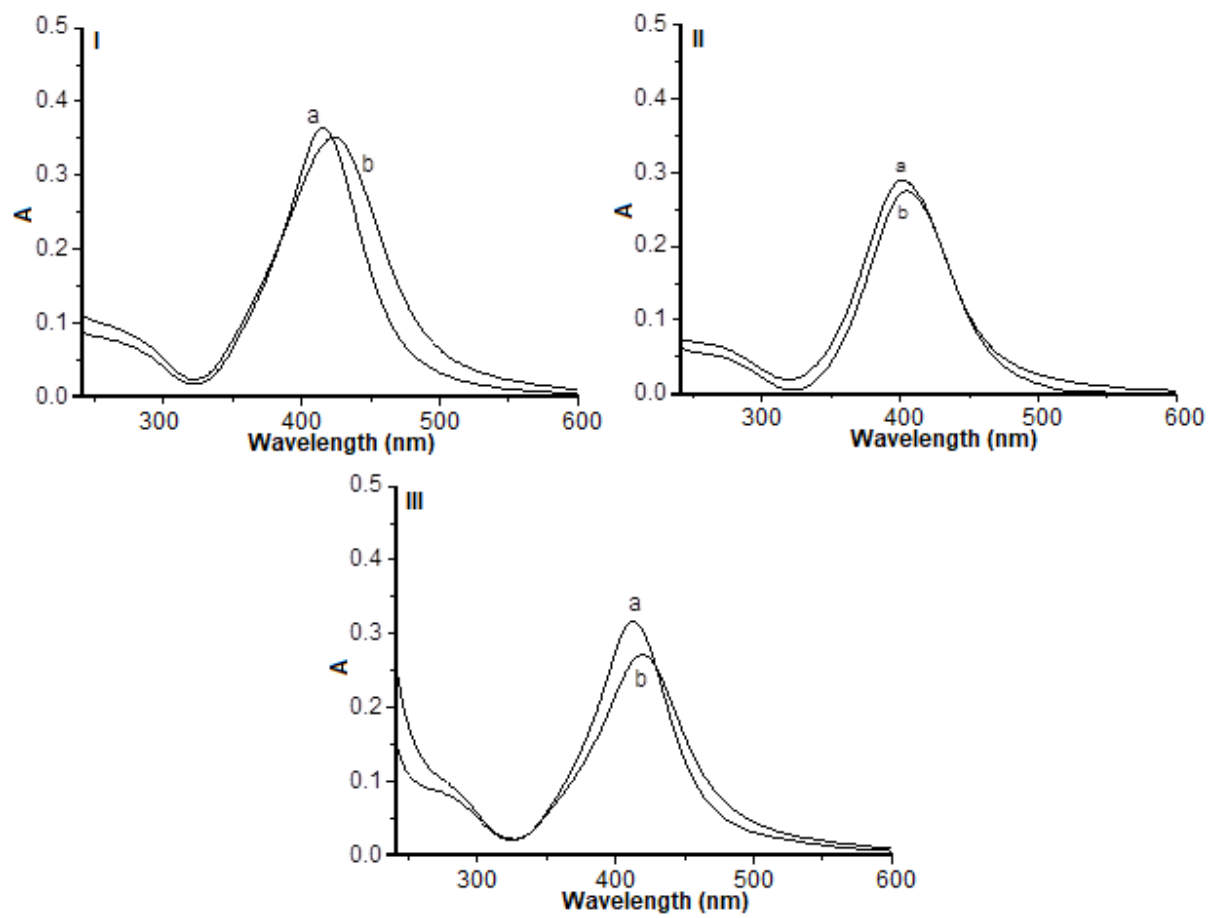

Fig 5. UV-Vis spectra of colloidal Ag nanoparticles prepared using the reducing agent of (I) ascorbic acid, (II) sodium borohydride, (III) hydrazine, and in each graph (a) freshly prepared and (b) after 4 weeks 
sodium borohydride, and hydrazine. After the colloids have been settled for 4 weeks, the change of the peak absorbance for ascorbic acid is small, although it shifted slightly to a larger wavelength. The peak of absorbance for colloid formed by use sodium borohydride does not change, but it does decrease a little. The peak of the absorbance decreases and shifts considerably for the colloid made by using the reducing agent of hydrazine. The trends for colloids formed by using glucose and sodium citrate are very similar.

The stability of the colloid is also critical for long-term use and storage of nanoparticles. Aggregation of nanoparticles to become larger particles will cause the colloid to form a suspension. The change in the UV-Vis spectrum indicates the stability of the colloid. As it was reported, the colloidal porous Pt-Au-Ag nanoparticles may be stable for up to 100 days [10]. Green synthesis of $\mathrm{Ag}$ nanoparticles using cowpea seeds can result in colloids that are stable for 11 months [16]. At $50^{\circ} \mathrm{C}$ colloidal of $\mathrm{Ag}$ nanoparticles-PVA-laccase is known to be stable for up to 13 days only [17].

\section{CONCLUSION}

The reducing agents significantly affect the physical and chemical properties of the Ag nanoparticles regarding shape, size, zeta potential, and stability. The produced colloids in PVA solution have UV-Vis peak absorbance in the range of $401-433 \mathrm{~nm}$. They have an fcc crystal system with a unit cell of 4.0906-4.0992 angstrom. As a reducing agent, ascorbic acid gives spherical shape, the uniform particle diameter of about $20 \mathrm{~nm}$, and zeta potential of $-10.4 \mathrm{mV}$. The colloid of $\mathrm{Ag}$ nanoparticles produced by ascorbic acid is also the most stable although it has slightly lower zeta potential than that of colloid obtained by sodium borohydride. The colloids produced using ascorbic acid may find applications for chemical sensors, an antibacterial agent, solar harvesting technology, and so on.

\section{ACKNOWLEDGEMENT}

The authors thank the Ministry of Research, Technology and Higher Education of Indonesia for the research funding. The research facilities provided by the Department of Chemistry, Universitas Gadjah Mada, Yogyakarta, Indonesia are much appreciated.

\section{REFERENCES}

[1] Alimunnisa, J., Ravichandran, K., and Meena, K.S., 2017, Synthesis and characterization of $\mathrm{Ag} @ \mathrm{SiO}_{2}$ core-shell nanoparticles for antibacterial and environmental applications, J. Mol. Liq., 231, 281287.
[2] Biao, L., Tan, S., Wang, Y., Guo, X., Fu, Y., Xu, F., Zu, Y., and Liu, Z., 2017, Synthesis, characterization and antibacterial study on the chitosan-functionalized ag nanoparticles, Mater. Sci. Eng., C, 76, 73-80.

[3] Iswarya, C.N., Daniel, S.C.G.K., and Sivakumar, M., 2016, Studies on L-histidine capped $\mathrm{Ag}$ and $\mathrm{Au}$ nanoparticles for dopamine detection, Mater. Sci. Eng., C, 75, 393-401.

[4] Li, H., He, Y., Liu, Z., Jiang, B., and Huang, Y., 2017, Rapid synthesis of broadband $\mathrm{Ag@OTiO} 2$ core-shell nanoparticles for solar energy conversion, Sol. Energy Mater. Sol. Cells, 166, 5260.

[5] Wu, Y., Li, C., Bai, J., and Wang, J., 2017, The fabrication of porous 4A-zeolite-supported $\mathrm{Ag}$ nanoparticles catalysts and its catalytic activity for styrene epoxidation, Results Phys., 7, 1616-1622.

[6] Kumar, A., Aerry, S., and Goia, D.V., 2016, Preparation of concentrated stable dispersions of uniform $\mathrm{Ag}$ nanoparticles using resorcinol as reductant, J. Colloid Interface Sci., 470, 196-203.

[7] Shervani, Z., and Yamamoto, Y., 2011, Carbohydrate-directed synthesis of silver and gold nanoparticles: effect of the structure of carbohydrates and reducing agents on the size and morphology of the composites, Carbohydr. Res., 346 (5), 651-658.

[8] Bozkurt, P.A., 2017, Sonochemical green synthesis of $\mathrm{Ag} / \mathrm{graphene}$ nanocomposite, Ultrason. Sonochem., 35 (Part A), 397-404.

[9] Khalilzadeh, M.A., and Borzoo, M., 2016, Green synthesis of silver nanoparticles using onion extract and their application for the preparation of a modified electrode for determination of ascorbic acid, J. Food Drug Anal., 24 (4), 796-803.

[10] Zhao, M., Zhong, N., and Ji, Y., 2017, Ultra-stable colloidal porous Pt-Au-Ag nanoparticles, Mater. Lett., 191, 38-41.

[11] Kumari, M., Pandey, S., Giri, V.P., Bhattacharya, A., Shukla, R., Mishra, A., and Nautiyal, C.S., 2016, Tailoring shape and size of biogenic silver nanoparticles to enhance antimicrobial efficacy against MDR bacteria, Microb. Pathog., 105, 346355.

[12] Yan, Y., Chen, K., Li, H., Hong, W., Hu, X., and Xu, Z., 2014, Capping effect of reducing agents and surfactants in synthesizing silver nanoplates, Trans. Nonferrous Met. Soc. China, 24 (11), 37323738.

[13] Chunfa, D., Xianglin, Z., Hao, C., and Chuanliang, C., 2016, Sodium alginate mediated route for the synthesis of monodisperse silver nanoparticles using glucose as reducing agents, Rare Met. Mater. Eng., 45 (2), 261-266. 
[14] Bhan, C., Brower, T.L., and Raghavan, D., 2013, SPR studies of the adsorption of silver/bovine serum albumin nanoparticles (Ag/BSA NPs) onto the model biological substrates, J. Colloid Interface Sci., 402, 40-49.

[15] Jayaprakash, N., Vijaya, J.J., Kaviyarasu, K., Kombaiah, K., Kennedy, L.J., Ramalingam, R.J., Munusamy, M.A., and Al-Lohedan, H.A., 2017, Green synthesis of $\mathrm{Ag}$ nanoparticles using Tamarind fruit extract for the antibacterial studies, $J$. Photochem. Photobiol., B, 169, 178-185.
[16] Mohammadi, S., Pourseyedi, S., and Amini, A., 2016, Green synthesis of silver nanoparticles with a long lasting stability using colloidal solution of cowpea seeds (Vigna sp. L), J. Environ. Chem. Eng., 4 (2), 2023-2032.

[17] Cunha, M.N.M., Felgueiras, H.P., Gouveia, I., and Zille, A., 2017, Synergistically enhanced stability of laccase immobilized on synthesized silver nanoparticles with water-soluble polymers, Colloids Surf., B, 154, 210-220. 